\title{
Downregulation of retinoblastoma protein is involved in the enhanced cytotoxicity of 4-hydroxytamoxifen plus mifepristone combination therapy versus antiestrogen monotherapy of human breast cancer
}

\author{
PATRICIA V. SCHOENLEIN ${ }^{1}$, MIN HOU ${ }^{1}$, JULIA S. SAMADDAR ${ }^{1}$, VIRGIL T. GADDY ${ }^{1}$, \\ MUTHUSAMY THANGARAJU ${ }^{2}$, JILL LEWIS ${ }^{3}$, MARIBETH JOHNSON ${ }^{4}$, \\ VADIVEL GANAPATHY ${ }^{2}$, ANDRE KALLAB ${ }^{5}$ and JOHN T. BARRETT ${ }^{6}$ \\ ${ }^{1}$ Departments of Cellular Biology and Anatomy, ${ }^{2}$ Biochemistry, ${ }^{3}$ Oral Biology, ${ }^{4}$ Statistics, \\ ${ }^{5}$ Medical Oncology, and ${ }^{6}$ Radiation Oncology, Medical College of Georgia, Augusta, GA 30912, USA
}

Received April 11,2007; Accepted May 16, 2007

\begin{abstract}
In this study, human MCF-7 breast cancer cells, which express functional estrogen and progesterone receptors, were used to compare the efficacy of combined antiestrogen plus antiprogestin therapy to antiestrogen monotherapy. Cells were treated with the antiestrogen 4-hydroxytamoxifen (4$\mathrm{OHT}$ ) and/or the antiprogestin mifepristone (MIF) and effects on cell proliferation (cytostatic action), cell cycle phase, the phosphorylation state of the tumor suppressor retinoblastoma protein $(\mathrm{Rb})$, and induction of active cell death (cytotoxic action) were determined. Combination hormonal therapy showed both increased cytostatic and cytotoxic activity as compared to either monotherapy. The increased cytostatic action was mediated by $\mathrm{Rb}$ activation; whereas, the cytotoxic (pro-apoptotic) action of combined hormonal therapy correlated to a significant reduction in $\mathrm{Rb}$ protein levels. To test the apparent role of $\mathrm{Rb}$ protein loss in the pro-apoptotic action of combined hormonal therapy, $\mathrm{Rb}$ was downregulated in MCF-7 cells using siRNA-targeting. The siRNA-mediated knockdown of $\mathrm{Rb}$ combined with 4-OHT therapy resulted in a pro-apoptotic action similar to that resulting from 4-OHT and MIF combination treatment, which included increased cell detachment from the monolayer, high-molecular-weight
\end{abstract}

Correspondence to: Dr P.V. Schoenlein, Department of Cellular Biology and Anatomy, 1459 Laney Walker Blvd., Medical College of Georgia, Augusta, GA 30912-2000, USA

E-mail: pschoenl@mail.mcg.edu

Abbreviations: ER, estrogen receptor; PR, progesterone receptor; $\mathrm{pRb}$, hypophosphorylated retinoblastoma protein; $\mathrm{ppRb}$, hyperphosphorylated retinoblastoma protein; 4-OHT, 4-hydroxytamoxifen; MIF, mifepristone; DEX, dexamethasone; PARP, poly-ADP-ribose polymerase

Key words: breast cancer, cell death, MCF-7, retinoblastoma protein, antiprogestin, antiestrogen genomic DNA fragmentation, and cleavage of poly ADP-ribose polymerase (PARP) and lamin A. From these studies, we conclude that $\mathrm{Rb}$ protein downregulation is required for 4OHT-treated, estrogen receptor positive $\left(\mathrm{ER}^{+}\right)$breast cancer cells to undergo active cell death. We discuss the potential of using an antiprogestin such as MIF plus antiestrogen treatment to more effectively downregulate $\mathrm{Rb}$ in $\mathrm{ER}^{+}$breast cancer cells to increase the overall cytotoxic action of hormonal therapy.

\section{Introduction}

Approximately $70 \%$ of breast tumors express the estrogen receptor (ER) and most of these tumors also express the progesterone receptor (PR). ER and PR, along with their cognate ligands, form multiprotein complexes that regulate the proliferation and differentiation of breast tissue. The ER is a ligand-activated transcription factor that recruits quiescent cells into G1 and shortens the G1-S phase transition. Estradiol (E2) binds and activates the ER and ER activation is mitogenic for the majority of $\mathrm{ER}^{+}$breast cancers (1-5). In breast tissue, E2-stimulated ER activity enhances expression of PR and concomitantly downregulates the levels of ER (3), while progesterone-activated PR suppresses estrogen-mediated ER activity, in part, by downregulating ER $(4,5)$. Thus, ER and $\mathrm{PR}$ expression is tightly linked in the majority of $\mathrm{ER}^{+}$breast cancers.

Approximately two-thirds of ER-expressing breast cancer tumors will respond to antiestrogens that antagonize the actions of estrogens by binding to ER in a manner competitive with estrogen $(6,7)$. The nonsteroidal antiestrogen tamoxifen is among the most effective specific therapies for estrogenresponsive breast cancer in women (8). Tamoxifen inhibits estrogen-mediated gene transcription (4) and significantly decreases the rates of disease recurrence and death $(7,9)$. The success of tamoxifen therapy has encouraged the development and testing of other synthetic steroid antagonists, referred to as selective estrogen receptor modifiers (SERMs), as potential therapeutic agents for hormone-dependent breast cancers 
(10). However, a major limitation of tamoxifen therapy, and antiestrogen therapy in general, is the high frequency of resistance that develops in patients (11). Thus, there is a high demand for new, more effective therapeutic and chemopreventive approaches for breast cancer.

Antiprogestins are a promising new class of mammary tumor inhibitors $(12,13)$. MIF, also designated RU486 (Roussel Uclaf, Population Council), was the first antiprogestational agent synthesized and tested $(14,15)$ and is considered to be the prototype antiprogestin. MIF is a steroid [17ß-hydroxy11ß-(4-dimethylaminophenyl)-17 $\alpha$-(prop-1-ynyl)estra-4,9-dien3-one] that has high affinity for PR, mediating its significant antiprogestational effects (15-19). When MIF binds to PR, progesterone is blocked from binding the $\mathrm{PR}$ and progesteronemediated transcription is inhibited $(20,21)$. MIF also binds the glucocorticoid receptor, blocking the binding of glucocorticoids and antagonizing glucocorticoid activity $(22,23)$. Also, in MCF-7 cells under certain cell contexts, i.e. measurement of reporter constructs, MIF can be a more potent antagonist of ER expression than progesterone (24-26).

In the laboratory setting, we and others have demonstrated that MIF is as effective as 4-OHT, an active metabolite of tamoxifen, at inhibiting breast cancer cell growth in culture (in vitro) $(27)$ and in human xenografts (in vivo) $(13,28)$. We have further demonstrated that MIF, in combination with 4-OHT therapy of breast cancer cells in vitro is superior to either agent alone (monotherapy) for the treatment of $\mathrm{ER}^{+}$, tamoxifen-sensitive or -resistant breast cancer cells (27-29). Most recently, MIF was shown to prevent Brca1-mediated mammary tumorigenesis in mice (30). These previous results are in agreement with studies by Bardon et al (31) and continue to provide support to the approach of treating $\mathrm{ER}^{+}$breast cancer with a combined antiestrogen and antiprogestin therapy.

To gain further support for the concept of combination antiestrogen and antiprogestin therapy for the treatment of $\mathrm{ER}^{+}$breast cancer, it is critical to understand the mechanism(s) of action of antiprogestins in inhibiting breast cancer cell growth when used as an adjuvant to antiestrogen therapy. In this study, we demonstrate that the increased antiproliferative action of 4-OHT plus MIF combination treatment as compared to either monotherapy is mediated by the ER, and PR, and involves (1) induction of cytostasis (growth arrest) mediated by active $\mathrm{Rb}$ and (2) increased cytotoxic action (induction of apoptosis) mediated, in part, by $\mathrm{Rb}$ protein downregulation. Importantly, we demonstrate that MIF used in combination with 4-OHT can induce a robust downregulation of $\mathrm{Rb}$ protein levels that is not seen in monotherapy-treated cells. We discuss the potential significance of using MIF to downregulate $\mathrm{Rb}$ in patients undergoing antiestrogen therapy.

\section{Materials and methods}

Cell culture. The MCF-7 human breast cancer cells (passage number: 149) were obtained from American Type Culture Collection (ATCC, Rockville, MD). The cells were routinely cultured in Dulbecco's modified Eagle's medium (DMEM) (Life Technologies, Inc., Rockville, MD), low glucose, containing $1 \mathrm{mM}$ sodium pyruvate (Life Technologies, Inc.), $10 \mu \mathrm{g} / \mathrm{ml}$ bovine insulin (Life Technologies, Inc.), and 10\% fetal bovine serum (FBS) (Life Technologies, Inc.). Cells were maintained in a $37^{\circ} \mathrm{C}, 5 \% \mathrm{CO}_{2}$ humidified incubator. Prior to experimental treatment, cells were estrogen- and progesterone-depleted by culturing in phenol red-free DMEM: Ham's F12 (Life Technologies, Inc.), supplemented with insulin $(10.0 \mu \mathrm{g} / \mathrm{ml})$ and decreasing concentrations of dextran-coated charcoal (DCC)-stripped serum (Hyclone Laboratories, Inc. Logan, UT) as previously described (27). The insulin was either removed from the medium for $24 \mathrm{~h}$ or immediately prior to treatment to minimize the contribution of the insulin and insulin-like growth factor receptor pathway. Cells were treated with 10 nM E2 (Sigma-Aldrich, St. Louis, MO), supplemented with or without $1 \mu \mathrm{M}$ 4-OHT (Sigma) and/or $10 \mu \mathrm{M}$ MIF (Sigma) as previously described (27). E2 was added to vehicle $(0.05 \% \mathrm{EtOH})$ and drug-treated cultures to stimulate PR levels and to maintain cell growth and proliferation in a standard fashion. E2 was not added to the E2 ablation groups. Dexamethasone (DEX) (Sigma) at a concentration of $15 \mu \mathrm{M}$ was used as a competitive inhibitor for MIF-mediated antiglucocorticoid effects and, where indicated, was added at the time of treatment.

MTT assay and statistical analysis. Cell survival was measured by an MTT (3-4,5-dimethylthiazol-2, 5-diphenyl tetrazolium bromide) colorimetric assay as previously described (32). The soluble MTT reagent (Sigma) was taken up by viable cells and reduced to the insoluble purple formazan product by mitochondrial dehydrogenase. The number of viable cells was proportional to the amount of formazan product in this assay. Cells were plated at a density of 5,000 cells per well in a 96-well plate and allowed to attach at $37^{\circ} \mathrm{C}$ for $24 \mathrm{~h}$. Cells were treated as indicated and incubated at $37^{\circ} \mathrm{C}$ until MTT assays were performed at appropriate times (24-96 h). Cells were fixed in situ with Tris/Formalin, washed once with water, and solubilized in $\mathrm{NaOH} / \mathrm{DMSO}$. The colored formazan product was quantified by absorbance at $570 \mathrm{~nm}$ using an ELISA reader (Tecan, Winselect). To analyze the significance of data generated from MTT assays, differences among groups were tested using analysis of variance (ANOVA), after correction for cell seeding variation per well per dish. Groups were analyzed within each time period using ANOVA and differences between the control and the treated groups were assessed using the Dunnett's post-hoc test. For the comparison over time of the treatment groups, data was analyzed in two ways. Both the raw data $\left(\mathrm{OD}_{570}\right.$ of six replicates/treatment; $\mathrm{n}=3$ at each time point) and the percent change of treatment to control $(n=3)$ were analyzed. Comparisons of the treatment groups over time were performed using a two-way ANOVA (treatment group and time) where a significant interaction would indicate different treatment responses over time. Tukey's post-hoc test was used to adjust for the multiple comparisons. Statistical significance was set at $\mathrm{p}<0.05$, and the results presented as mean \pm SD. SAS V 8 was used for all analyses.

\section{Cell counting and microscopy}

Cell counting. Cells detached from the cell monolayer, designated as floating (detached) cells, were counted independently of the monolayer cells. Monolayer (attached) cells were trypsinized and counted. Cell counts were performed in a hemocytometer using $10 \mu \mathrm{l}$ of cell suspension stained with 
trypan blue (TB) $(0.3 \%$ in phosphate buffered saline) to determine viability.

Light microscopy. Live images of MCF-7 breast cancer cells treated with 4-OHT and MIF were captured at x200 magnification with Spot software using phase-contrast microscopy.

Electron microscopy. Floating cells were collected from the medium and processed separately from, or combined with, the attached cells. Monolayer cells were harvested by trypsinization. Cells were washed twice with PBS and fixed with ice-cold glutaraldehyde (3\% in $0.1 \mathrm{M}$ cacodylate buffer, $\mathrm{pH}$ 7.4) for $30 \mathrm{~min}$. After washing in PBS, the cells were post-fixed in $\mathrm{OsO}_{4}$, embedded in Epon, cut into 0.1- $\mu \mathrm{m}$ thin sections, stained with uranylacetate/lead citrate (Fluka), and viewed in a Phillips EM 400 electron microscope. For light microscopic investigation, $1-\mu \mathrm{m}$ sections were stained with toluidine blue.

Western blotting experiments and densitometry. At each time point, monolayer cells were lysed directly in the culture dishes using a buffer consisting of 5\% B-mercaptoethanol, $0.12 \mathrm{M}$ Tris ( $\mathrm{pH} 6.8$ ), 20\% glycerol, and 4\% SDS. The samples were heated at $100^{\circ} \mathrm{C}$ for $5 \mathrm{~min}$ to inactivate any proteases and denature proteins. Fifty to $100 \mu \mathrm{g}$ of protein lysate were loaded into each well of either $7.5 \%$ or $10 \%$ polyacrylamide gels, separated by SDS-PAGE, and transferred to nitrocellulose membranes (Hybond ${ }^{\mathrm{TM}} \mathrm{ECL}^{\mathrm{TM}}$, Amersham Pharmacia, Piscataway, NJ) by electroblotting. Membranes were blocked in 5\% milk in 1X TBST (Tris-buffered saline and $0.05 \%$ Tween-20) and incubated with primary antibody as recommended by the manufacturer. Membranes were incubated with appropriate $2^{\circ}$ antibodies that were conjugated with horseradish peroxidase. Blots were washed in 1X TBST and in 1X TBS (TBST without Tween-20) three times. Immunodetection was performed using the Enhanced Chemiluminescence Detection system (ECL, Amersham Pharmacia) and exposure to Kodak Scientific Imaging Film (Eastman Kodak Company, Rochester, NY). The Rb antibody (1:1000 dilution, Santa Cruz, CA) was a 10 goat affinity-purified polyclonal antibody raised against a C-terminal peptide that recognizes both the hyperphosphorylated and hypophosphorylated forms of the human $\mathrm{Rb}$ protein. A polyclonal antibody to cleaved PARP and cleaved lamin A (Cell Signaling Technology, Beverly, MA) was used at a 1:1000 dilution. Membranes also were probed with $\beta$-actin antibody (Sigma), and the intenstity of $\beta$-actin signal was used to correct for variations in protein loading or transfer from gel to membrane. Densitometry was performed using Kodak Digital Science ${ }^{\mathrm{TM}}$ and Kodak Digital Science 1 D image analysis software (Eastman Kodak Company). One-way ANOVA (within time) was used to determine differences between all five treatments and a Dunnett's test was used to compare all treatments to the control cells (E2 only). Two-way ANOVA within time, (MIF present or absent, 4-OHT present or absent) was performed to determine synergy using actual pixel data.

Flow cytometry. Monolayer cells were trypsinized with $0.25 \%$ trypsin, placed into fresh DMEM/Hams F12 medium containing 5\% DCC FBS to neutralize the trypsin, and counted with a hemocytometer. Cells $\left(1 \times 10^{6}\right)$ were placed into $15-\mathrm{ml}$ culture tubes that contained $10 \mathrm{ml}$ of $70 \% \mathrm{EtOH}$ overnight at $4^{\circ} \mathrm{C}$. Fixed cells were centrifuged for $5 \mathrm{~min}$ at $2,000 \mathrm{x} \mathrm{g}$, resuspended in $1 \mathrm{ml}$ ice-cold $\mathrm{PBS} / 0.1 \%$ Triton-X containing $50 \mu \mathrm{g} / \mathrm{ml}$ RNase A (Sigma) and $100 \mu \mathrm{g} / \mathrm{ml}$ propidium iodide (Sigma), and incubated in the dark for $30 \mathrm{~min}$. Immediately prior to analysis, cells were passaged through a 25-gauge needle and filtered by passing through nylon mesh (Spectrum, Laguna Hills, CA; $41-\mu \mathrm{m}$ size). The stained cells were analyzed in a fluorescence-activated cell sorter (FACSCaliber, Becton Dickinson, San Jose, CA) within $4 \mathrm{~h}$ at a wavelength of $488 \mathrm{~nm}$ (argon laser) using the Cell Quest program (Becton Dickinson). For each sample, 10,000 cells were analyzed. Aggregates were excluded from the analysis. The percentage of cells in G0-G1, S, and G2-M phases was determined using the ModFit program (Topsham, ME).

Agarose gel electrophoresis of fragmented DNA. To detect oligonucleosomal DNA laddering, the method of Ishida et al (33) was performed. Briefly, total oligonucleosomal DNA obtained from $2 \times 10^{7}$ cells was loaded into one lane of a $2 \%$ agarose gel and subjected to conventional gel electrophoresis. To detect high molecular weight (HMW) DNA degradation, pulsed field gel electrophoresis analysis was performed as previously described (34-36). In brief, chromosomal DNA was embedded into agarose plugs and deproteinized in situ in EST lysis buffer [500 mM EDTA (pH 9.0) $1.0 \%$ sodium lauroylsarcosine, $2 \mathrm{mg} / \mathrm{ml}$ proteinase $\mathrm{K}$ ] (Boehringer Mannheim, Indianopolis, IN). Equivalent amounts of the HMW DNA was fractionated on a $1 \%$ agarose gel using the CHEF DRII electrophoretic system (BioRad, Hercules, CA). The gel was stained with ethidium bromide and photographed while exposed to UV light.

Downregulation of $R b$ with RNA interference. RNA interference technology using siRNA to Rb (Dharmacon RNA Technologies) was performed according to the manufacturer's protocol. Cells $\left(1.5 \times 10^{5}\right)$ were seeded in 6-well corning dishes in antibiotic-free DMEM/F12 medium containing insulin. Twenty-four $\mathrm{h}$ following seeding, cells were washed and treated with either Rb-targeting siRNA $(0.25 \mathrm{nM}$ or $0.5 \mathrm{nM})$ or non-targeting siRNA $(0.25$ or $0.5 \mathrm{nM})$. Forty-eight $\mathrm{h}$ after siRNA treatment, cells were treated with either E2 $(10.0 \mathrm{nM})$ or E2 plus 4-OHT $(1.0 \mu \mathrm{M})$. At appropriate times, cells were harvested for either protein analysis, cell counts, or EM analysis.

Reverse transcription RT-PCR. Total RNA was isolated from cells using Trizol reagent (Invitrogen Carlsbad, CA). Semiquantitative reverse transcriptase-polymerase chain reaction (RT-PCR) analysis was performed, as previously described using $2 \mu \mathrm{g}$ RNA and the GeneAmp PCR system (Roche) (37). Hypoxanthine phosphoribosyltransferase $1 \mathrm{mRNA}$ was used as the internal control. Gene-specific PRC primers were designed based on the nucleotide sequences available in Genbank. For the Rb110 PCR, the primer sequences were as follows: forward primer, 5'-CTTTATTGGCGTGCGCTCT TG-3'; reverse primer, 5'-TGCTCAGACAGAAGGCGTTCA3 '. For GAPDH, the primer sequences were as follows: forward 
A

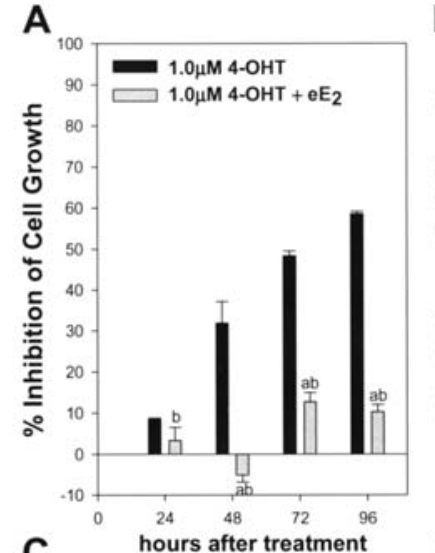

B

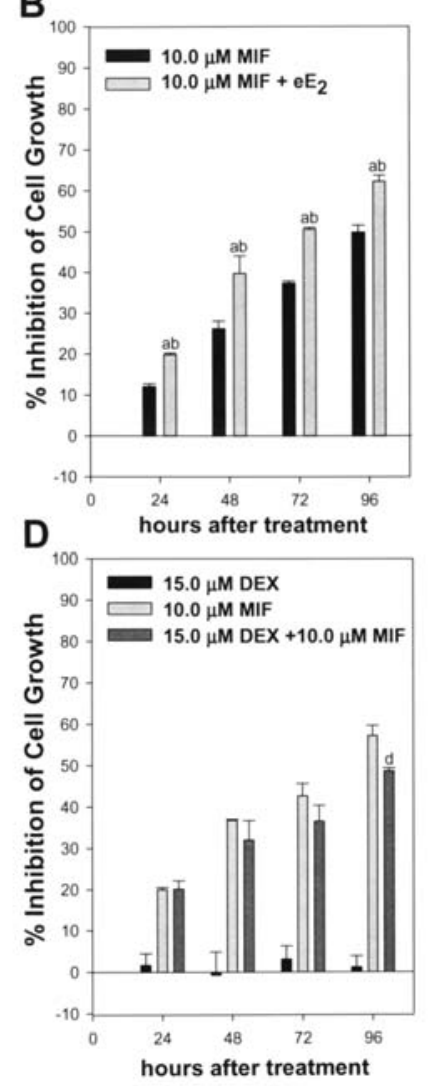

Table I. Inhibitory effect of MIF, progesterone (P), and their combination on MCF-7 cell growth in vitro (time-response relationship MTT assay).

$\%$ Inhibition of cell growth (mean \pm SEM) and hours after treatment

\begin{tabular}{lccc} 
Hormonal treatment $^{\mathrm{a}}$ & 24 & 48 & 72 \\
\cline { 2 - 4 } MIF $1 \mu \mathrm{M}$ & $3.6 \pm 9.9$ & $3.4 \pm 2.3$ & $1.9 \pm 2.0$ \\
MIF $5 \mu \mathrm{M}$ & $9.9 \pm 4.9$ & $13.4 \pm 5.0^{\mathrm{b}}$ & $20.0 \pm 2.2^{\mathrm{b}, \mathrm{d}}$ \\
MIF $10 \mu \mathrm{M}$ & $21.6 \pm 5.2^{\mathrm{b}, \mathrm{d}}$ & $31.5 \pm 6.1^{\mathrm{b}, \mathrm{d}}$ & $44.1 \pm 2.3^{\mathrm{b}, \mathrm{d}}$ \\
P $1 \mu \mathrm{M}$ & $6.7 \pm 6.8$ & $4.2 \pm 5.8$ & $5.9 \pm 1.6^{\mathrm{b}}$ \\
P $5 \mu \mathrm{M}$ & $12.0 \pm 8.1$ & $6.9 \pm 10.0$ & $9.4 \pm 1.1^{\mathrm{b}, \mathrm{d}}$ \\
P $10.0 \mu \mathrm{M}$ & $14.9 \pm 6.6^{\mathrm{d}}$ & $11.7 \pm 3.7^{\mathrm{d}}$ & $13.8 \pm 2.0^{\mathrm{b}, \mathrm{d}}$ \\
MIF $1 \mu \mathrm{M}+\mathrm{P} 1 \mu \mathrm{M}$ & $13.2 \pm 6.2$ & $10.0 \pm 6.6$ & $12.5 \pm 1.7^{\mathrm{b}, \mathrm{c}}$ \\
MIF $5 \mu \mathrm{M}+\mathrm{P} 5 \mu \mathrm{M}$ & $26.3 \pm 7.6^{\mathrm{b}, \mathrm{c}}$ & $21.2 \pm 7.6^{\mathrm{b}, \mathrm{c}}$ & $30.9 \pm 4.0^{\mathrm{b}, \mathrm{c}}$ \\
MIF $10 \mu \mathrm{M}+\mathrm{P} 10 \mu \mathrm{M}$ & $37.6 \pm 4.7^{\mathrm{b}, \mathrm{c}}$ & $47.2 \pm 2.2^{\mathrm{b}, \mathrm{c}}$ & $59.0 \pm 3.5^{\mathrm{b}, \mathrm{c}}$ \\
\hline
\end{tabular}

${ }^{a}$ Cells were treated in the presence of $10 \mathrm{nM} \mathrm{E2}$; cells growing in E2 alone were designated as control group and their growth at 24,48 , and $72 \mathrm{~h}$ was

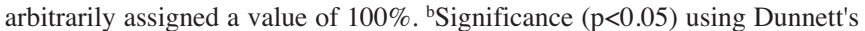
t-test when all treatment groups were compared to the E2 control group by ANOVA. ${ }^{\mathrm{C} S i g n i f i c a n c e}(\mathrm{p}<0.05)$ when combination therapy was compared to either monotherapy. ${ }^{\mathrm{d}}$ Monotherapies at a specific time point following treatment and at the same concentration were significantly different from each other $(\mathrm{p}<0.05)$, e.g. the percent inhibition resulting from $\mathrm{P}(10 \mu \mathrm{M})$ was different from MIF $(10 \mu \mathrm{M}) 24 \mathrm{~h}$ following treatment. For this analysis, raw data generated from the MTT assay were analyzed so that each treatment group represents the analysis of 18 values, six values each derived from 3 independent experiments. Variation within samples within each 96-well plate was evaluated and this variation was corrected as part of the statistical analysis

treatment. Results are expressed as percent inhibition of control (ethanol vehicle $+\mathrm{E} 2$, set at 100\% viable) obtained by MTT assay. Data points represent the mean of six replicates each in three independent experiments. Statistical analyses were performed using one-way analysis of variance with a Newman-Keuls multiple comparison post-test to determine significance $(p<0.05)$ between treatment groups. A, $\mathrm{eE}_{2}$ reversed 4-OHT-mediated growth inhibition. $\mathrm{B}, \mathrm{eE}_{2}$ enhanced MIF-induced growth inhibition. $\mathrm{C}_{2} \mathrm{eE}_{2}$ did not effectively reverse growth inhibition induced by combination 4-OHT plus MIF therapy as compared to $\mathrm{eE}_{2}$ reversal of 4-OHT-induced growth inhibition. D, excess dexamethasone (DEX) was relatively ineffective in reversing growth inhibition induced by MIF therapy. Statistical analysis was performed using one-way analysis of variance with a Tukey multiple comparison post-hoc test to determine significance $(\mathrm{p}<0.05)$ between treatment groups or a Dunnett's test when treatment groups were only compared to the E2 control group within time. (A- C) ${ }^{\mathrm{a}}$ For all treatment groups compared to the E2 control, except $1.0 \mu \mathrm{M} 4-\mathrm{OHT}+\mathrm{eE}_{2}$ at $24 \mathrm{~h}$ a statistical difference $(<0.05)$ was observed over time using Dunnett's t-test. ${ }^{b} \mathrm{~A}$ statistically significant difference was observed between the indicated treatment in the presence versus absence of excess E2. ${ }^{\mathrm{c} C o m b i n a t i o n}$ therapy was statistically different from 4-OHT (A) and MIF (B) monotherapy, and ANOVA analysis followed by a Tukey post-hoc test demonstrated an interaction of 4-OHT and MIF that increased over time. (D) The $15.0 \mu \mathrm{M}$ DEX treatment groups at $24,48,72$ and $96 \mathrm{~h}$ as compared to the E2 control group did not show statistical significance. ${ }^{\mathrm{d}}$ DEX reversed only $10 \%$ of MIF's antiproliferative effect by $96 \mathrm{~h}$.

primer, 5'-ATGCTGGCGCTGAGTACGTC-3'; reverse primer, 5'-GAGGAGTGGGTGTCGCTGTT-3'. The PCR products were separated on a $2 \%$ agarose/ethidium bromide gel. The size of the amplified RB110 product was 565 base pairs; the HPRT was 613 base pairs.

\section{Results}

The antiproliferative effects of 4-OHT when used in combination with MIF were not effectively blocked by excess

E2. In previous studies, we demonstrated that 4-OHT plus MIF combination therapy is more effective than either monotherapy in inhibiting breast cancer cell growth (27-28). However, we did not analyze how E2 affected the growth inhibitory response of hormone-dependent breast cancer cells to MIF or combination hormonal therapy, nor did we determine the mechanism(s) underlying the increased efficacy of combined 4-OHT plus MIF therapy.

Based on the fact that excess E2 $(1.0 \mu \mathrm{M})$ completely blocks 4-OHT binding to the ER receptor (data not shown) and has been used in our previous studies to completely block 4-OHT antiproliferative action (27), we used $1.0 \mu \mathrm{M}$ E2 to characterize excess E2 effects on MIF action when used as a monotherapy and in combination with 4-OHT. MCF-7 cells were treated with hormones in the presence or absence of $1.0 \mu \mathrm{M}$ E2 (designated $\mathrm{eE}_{2}$ in Fig. 1A-C) and cells were incubated for 24-96 h prior to harvest. Although E2 completely abrogated 4-OHT-mediated growth inhibition after $48 \mathrm{~h}$ of treatment (Fig. 1A), excess E2 did not inhibit MIF action (Fig. 1B). In fact, excess E2 enhanced MIF-mediated inhibition of cell growth by approximately $15 \%$ at each of the time periods analyzed (Fig. 1B). Importantly, excess E2 elicited only a $10 \%$ reduction in the growth inhibition effects of combination therapy, which was significantly more effective in inhibiting MCF-7 breast cancer cell growth than either monotherapy (Fig. 1C). Statistical analysis demonstrated that 
A
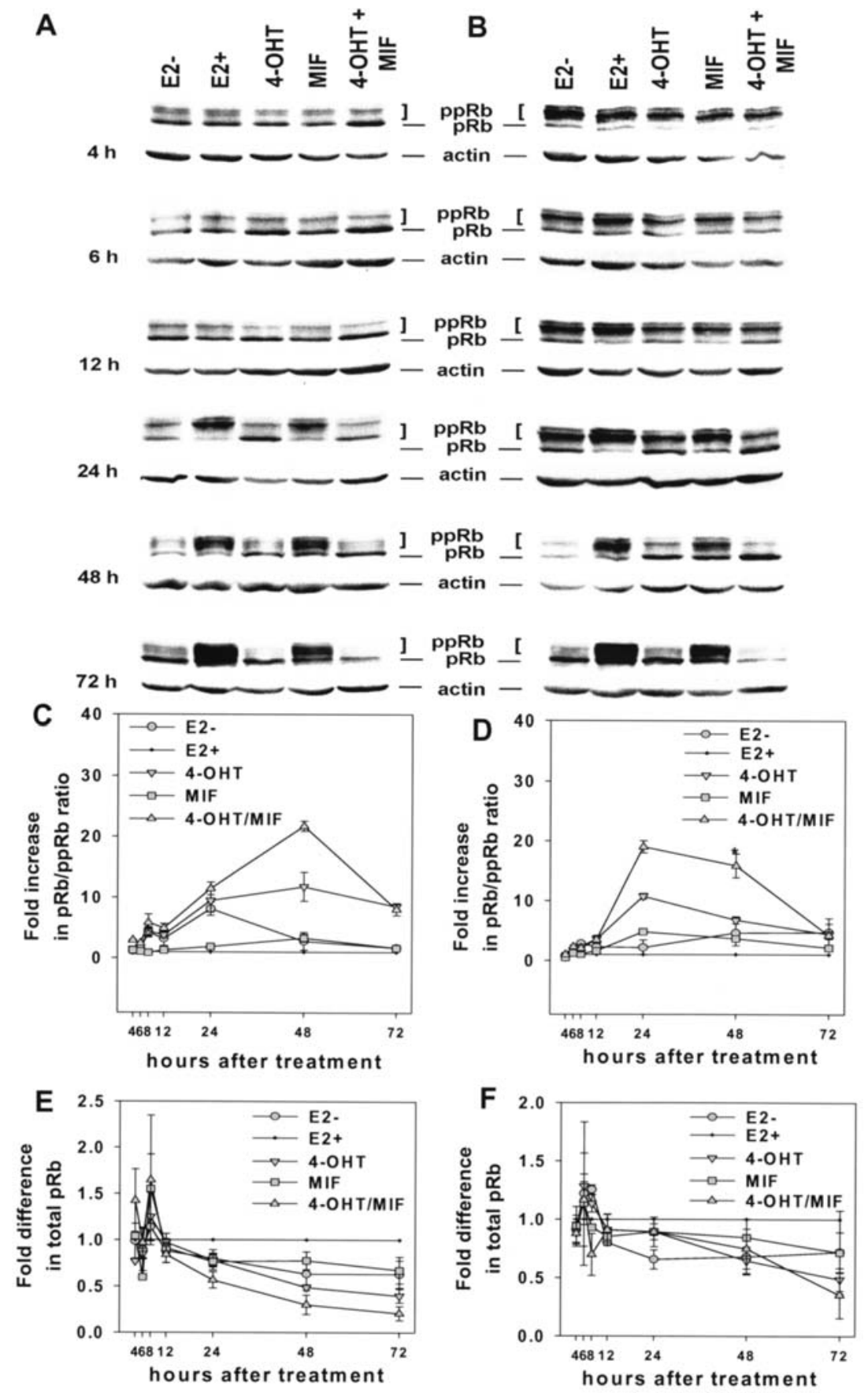

Figure 2. 4-OHT and MIF treatments affected Rb activation and subsequent downregulation in MCF-7 breast cancer cells. After hormone withdrawal, transiently arrested MCF-7 cells (A, C, E, without insulin for $24 \mathrm{~h}$ ) and actively growing MCF-7 cells (B, D, F, without insulin at time of treatment) were treated with 4-OHT $(1.0 \mu \mathrm{M})$, MIF $(10.0 \mu \mathrm{M})$ or their combination. Treatment included addition of $10 \mathrm{nM}$ E2, except in the E2 ablation control. At the indicated times, cells were harvested and the status of $\mathrm{Rb}$ phosphorylation was analyzed as described in Materials and methods. In all treatment groups, $\mathrm{Rb}$ was activated relative to control (E2 alone). A graphical representation of the increased ratio of hypophosphorylated vs hyperphosphorylated $\mathrm{Rb}(\mathrm{pRb} / \mathrm{ppRb}$ ), in MCF-7 cells is shown (C-F). Quantitation of the signal intensity of $\mathrm{pRb} / \mathrm{ppRb}$ demonstrated a statistically significant $(\mathrm{p}<0.05)$ increase in $\mathrm{Rb}$ activation at 24 and $48 \mathrm{~h}$ of 4-OHT, MIF and 4-OHT plus MIF treatment as compared to E2 alone (C and D) and further demonstrated a synergistic activation (*) of pRb in cycling cells in response to combination therapy at $48 \mathrm{~h}$ following treatment as compared to either monotherapy or E2 ablation (C). A statistically significant $(\mathrm{p}<0.05)$ overall downregulation in total Rb protein was seen with treatment over time in MCF-7 cells at 24, 48 and $72 \mathrm{~h}$ of treatment $(\mathrm{E}$ and $\mathrm{F})$, with the exception of the MIF treatment of cycling cells $(\mathrm{F})$. Values for $\mathrm{pRb}$ and $\mathrm{ppRb}$ signal intensities were averaged from three independent experiments (mean \pm $\mathrm{SE}$ ) after corrections for loading using B-actin signal intensity. The signal intensity of Rb forms in the E2-treated group (E2 were arbitrarily assigned a value of 1. All treatment groups were compared to the E2 group. The ratio of hypophosphorylated $\mathrm{Rb}$ and hyperphosphorylated Rb was plotted using Sigma Plot software. Densitometry was performed using a Kodak Imager and Kodak Scientific Imaging Software.

the differences between treatments were significant and that these differences did not change across time. These data provide strong evidence that 4-OHT acts through the ER, and MIF plus 4-OHT combination therapy effectively reverses the growth-promoting action of E2.
We were unable to use progesterone to reverse the effects of MIF because progesterone itself, at doses required to compete with MIF-mediated antiproliferative effects $(>1.0 \mu \mathrm{M})$, inhibited MCF-7 breast cancer growth (Table I). A similar antiproliferative activity of progesterone has been previously 

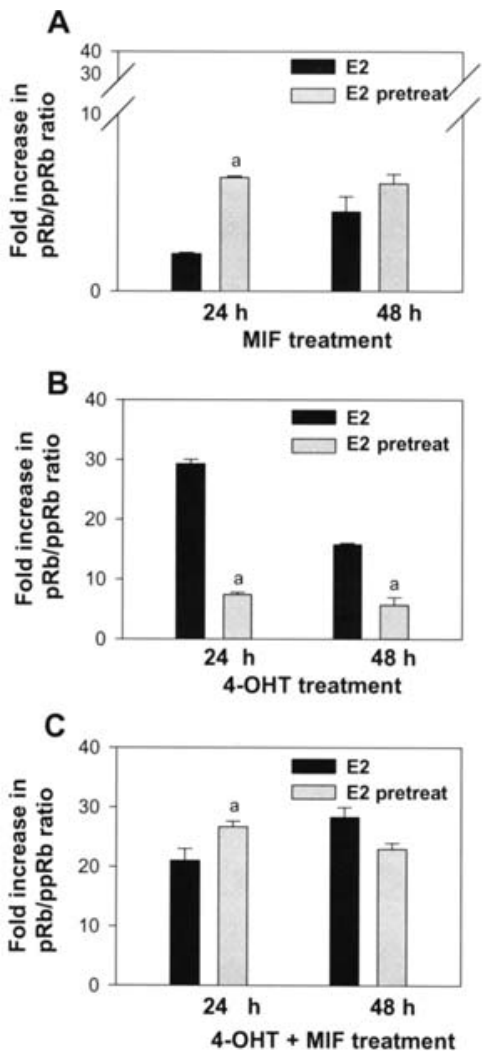

Figure 3. Differential effects of E2 pretreatment on 4-OHT- and MIF-mediated $\mathrm{Rb}$ activation. Following insulin removal from the medium for $24 \mathrm{~h}, \mathrm{MCF}-7$ cells were pretreated for 16-24 h with $10.0 \mathrm{nM} \mathrm{E2}$ and then treated with 4-OHT, MIF, or their combination. At the indicated times, cells were harvested and analyzed as described in Materials and methods. (A-C) Graphical representation of the $\mathrm{pRb}: \mathrm{ppRb}$ ratio in MCF-7 cells. The ratio of $\mathrm{pRb}: \mathrm{ppRb}$ and the total amount of $\mathrm{Rb}$ was corrected for loading using $\beta$-actin. The treatment groups were 4-OHT (A), MIF (B) or 4-OHT plus MIF (C). The numbers are the mean $\pm \mathrm{SE}$ of two independent experiments. ${ }^{\text {a Significance }}$ $(\mathrm{p}<0.05)$ between the E2 versus E2 pretreatment groups, within time and drug treatment $(\mathrm{A}-\mathrm{C})$.

demonstrated in other cell systems (38). However, MIF action on MCF-7 cells appears to require the PR because $10.0 \mu \mathrm{M}$ MIF treatment does not show significant antiproliferative effects on ER- and PR-negative MDA-231 cells (data not shown). We also determined that MIF action is not mediated through MIF binding to the glucocorticoid receptor $(20,21)$ because dexamethasone (DEX) is unable to reverse the inhibitory action of $10.0 \mu \mathrm{M}$ MIF during a 24- to 72-h treatment regimen (Fig. 1D). Collectively, these data indicate that the majority of 4-OHT and MIF action involves ER- and PRmediated processes, respectively.

4-OHT plus MIF combined therapy affect $R b$ via a bi-modal mechanism with $R b$ activation followed by $R b$ downregulation. Our published studies demonstrated a role for $\mathrm{Rb}$ in the response of breast cancer cells to 4-OHT or MIF monotherapy, but did not determine a role for $\mathrm{Rb}$ in the increased efficacy of 4-OHT plus MIF combination therapy (28). To determine if $\mathrm{Rb}$ is a key effector in the improved cytostatic and/or cytotoxic action of combination therapy, we analyzed the effect of 4-OHT and/or MIF treatment on Rb activation (reduced phosphorylation) and on total $\mathrm{Rb}$ protein levels across time. Two treatment conditions were used for these
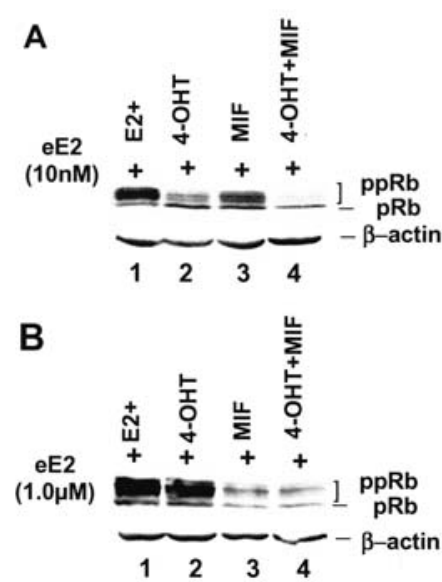

Figure 4. Excess E2 blocks 4-OHT, but not MIF-mediated Rb effects. Following insulin removal from the medium for $24 \mathrm{~h}, \mathrm{MCF}-7$ cells were treated with 4-OHT and/or MIF in the presence of either $10 \mathrm{nM} \mathrm{E2} \mathrm{(A)} \mathrm{or}$ $1.0 \mu \mathrm{M} \mathrm{E} 2(\mathrm{~B})$. At $72 \mathrm{~h}$, cells were harvested and analyzed for Rb status as described in Materials and methods.

studies and cells were analyzed 12-96 $\mathrm{h}$ after treatment. In the first condition, insulin was washed out $24 \mathrm{~h}$ prior to hormonal treatment to place MCF-7 cells in a relatively synchronous, growth-arrested population as previously described (39). In the second condition, insulin was not removed from the culture medium until the time of treatment to maintain a relatively asynchronous dividing cell population. The phosphorylation status of $\mathrm{Rb}$ was determined by immunoblot analysis. Quantitation of the hypophosphorylated $\mathrm{Rb}(\mathrm{pRb})$, and hyperphosphorylated $\mathrm{Rb}$ (ppRb), was performed using densitometry from 3 independent experiments and is presented as a ratio of $\mathrm{pRb}$ :ppRb.

Fig. 2A, C and E illustrates the effects of hormonal treatment when insulin is withdrawn from the culture medium $24 \mathrm{~h}$ prior to treatment. The removal of insulin for $24 \mathrm{~h}$ resulted in a population of MCF-7 cells expressing predominantly $\mathrm{pRb}$. E2 ultimately inactivated $\mathrm{Rb}$, inducing a time-dependent conversion of hypophosphorylated to hyperphosphorylated $\mathrm{Rb}$ (pRb to $\mathrm{ppRb}$ ). MIF minimally inhibited the E2-mediated conversion of $\mathrm{pRb}$ to $\mathrm{ppRb}$. In contrast, 4-OHT and combination therapy effectively maintained $\mathrm{Rb}$ in the hypophosphorylated state, with combination treatment being most effective in blocking the conversion of $\mathrm{pRb}$ to $\mathrm{ppRb}$. Fig. 2B, $\mathrm{D}$ and $\mathrm{F}$ shows how $\mathrm{Rb}$ is affected by hormonal therapy in an asynchronous dividing cell population. Cells grown in insulin until the time of treatment expressed hyperphosphorylated $\mathrm{Rb}$. E2 treatment maintained $\mathrm{Rb}$ in the inactive, hyperphosphorylated state, while 4-OHT and, to a lesser extent, MIF monotherapies activated $\mathrm{Rb}$ (induced a conversion of $\mathrm{Rb}$ from a hyperphosphorylated to a hypophosphorylated state). Clearly, 4-OHT and MIF combination treatment more effectively activated $\mathrm{Rb}$ than either monotherapy. So, under both treatment conditions, analysis of the $\mathrm{pRb}: \mathrm{ppRb}$ ratio showed that combination therapy was significantly more effective than either monotherapy at converting or maintaining $\mathrm{Rb}$ in a hypophosphorylated state, regardless of cell cycle status. Interestingly, in all treatment groups with the exception of MIF treatment of growth-arrested MCF-7 cells (Fig. 2E and F), a significant decrease in total $\mathrm{Rb}$ protein was observed after 
Table II. 4-OHT and MIF treatment arrested cells in the G0/G1 and $\mathrm{G} 2$ phase of the cell cycle.

\begin{tabular}{|c|c|c|c|}
\hline & $\% \mathrm{G} 0 / \mathrm{G} 1$ & $\% \mathrm{G} 2$ & $\% \mathrm{~S}$ \\
\hline \multicolumn{4}{|l|}{$24 \mathrm{~h}$} \\
\hline $\mathrm{E} 2^{-}$ & $75.6 \pm 0.1^{\mathrm{b}}$ & $7.1 \pm 0.8$ & $17.3 \pm 0.7^{b}$ \\
\hline $\mathrm{E}^{+}+$ & $56.8 \pm 0.2$ & $6.1 \pm 1.0$ & $37.1 \pm 1.3$ \\
\hline 4-OHT & $74.1 \pm 0.7^{\mathrm{b}}$ & $7.1 \pm 0.2$ & $18.8 \pm 0.5^{\mathrm{b}}$ \\
\hline MIF & $64.8 \pm 0.9^{\mathrm{b}}$ & $2.4 \pm 0.2^{\mathrm{b}}$ & $32.8 \pm 0.7^{b}$ \\
\hline 4-OHT + MIF & $80.7 \pm 0.4^{\mathrm{b}, \mathrm{c}}$ & $4.4 \pm 0.1$ & $14.9 \pm 0.3^{\mathrm{b}, \mathrm{c}}$ \\
\hline \multicolumn{4}{|l|}{$48 \mathrm{~h}$} \\
\hline E2- & $88.8 \pm 0.5^{\mathrm{b}}$ & $3.6 \pm 0.1^{\mathrm{b}}$ & $7.7 \pm 0.7^{b}$ \\
\hline $\mathrm{E} 2^{+}$ & $76.6 \pm 1.3$ & $5.0 \pm 0.2$ & $18.4 \pm 1.1$ \\
\hline 4-OHT & $89.4 \pm 0.1^{\mathrm{b}}$ & $3.6 \pm 0.2^{\mathrm{b}}$ & $7.0 \pm 0.2^{\mathrm{b}}$ \\
\hline MIF & $82.2 \pm 0.1^{\mathrm{b}}$ & $5.7 \pm 0.0$ & $12.1 \pm 0.1^{\mathrm{b}}$ \\
\hline 4-OHT + MIF & $90.3 \pm 0.2^{\mathrm{b}}$ & $4.1 \pm 0.1$ & $5.7 \pm 0.3^{\mathrm{b}}$ \\
\hline \multicolumn{4}{|l|}{$72 \mathrm{~h}$} \\
\hline $\mathrm{E} 2^{-}$ & $87.8 \pm 1.0^{\mathrm{b}}$ & $5.2 \pm 0.0$ & $6.99 \pm 1.1^{\mathrm{b}}$ \\
\hline $\mathrm{E}^{+}$ & $78.1 \pm 0.1$ & $6.7 \pm 0.1$ & $15.1 \pm 0.0$ \\
\hline 4-OHT & $91.1 \pm 0.6^{\mathrm{b}}$ & $3.5 \pm 0.6^{\mathrm{b}}$ & $5.4 \pm 0.0^{\mathrm{b}}$ \\
\hline MIF & $81.7 \pm 0.8$ & $5.3 \pm 0.0$ & $13.0 \pm 0.8$ \\
\hline 4-OHT + MIF & $92.1 \pm 1.0^{\mathrm{b}}$ & $3.2 \pm 0.5^{\mathrm{b}}$ & $4.7 \pm 0.5^{\mathrm{b}}$ \\
\hline
\end{tabular}

MCF-7 cells were treated as described in Materials and methods with $1 \mu \mathrm{M}$ 4-OHT, $10 \mu \mathrm{M}$ MIF or their combination (1 $\mu \mathrm{M} 4-\mathrm{OHT}+10 \mu \mathrm{M} \mathrm{MIF})$. Twenty-four $\mathrm{h}$ prior to treatment with hormones, cells were seeded in DMEM/F12 containing 5\% DCC serum. E2 (10 nM) was present in the 4-OHT, MIF, and 4-OHT + MIF treatment groups. For each treatment group, two independent experiments were performed and the mean was calculated. SEM, standard error of the mean. ${ }^{b}$ Dunnetts test determined a significant difference $(\mathrm{p}<0.05)$ of the treatment group compared to MCF-7 cells growing in the presence of only E2 $\left(\mathrm{E} 2{ }^{+}\right) .{ }^{\mathrm{c}} \mathrm{A}$ post-hoc Tukey's test determined a significant difference $(\mathrm{p}<0.05)$ between the 4-OHT + MIF combination therapy and each monotherapy.

$48 \mathrm{~h}$ of treatment, and persisted at least until $96 \mathrm{~h}$ of treatment (Fig. 2E and F, and data not shown). Under both treatment scenarios, combined therapy induced the greatest level of $\mathrm{Rb}$ downregulation.

4-OHT and MIF affect Rb in an ER-and PR-dependent manner. ER and PR receptor involvement was demonstrated for both 4-OHT- and MIF-induced $\mathrm{pRb}$ activation and downregulation. For these studies, cells were pretreated with E2 to upregulate PR and downregulate ER; a well-characterized transcriptionally-regulated outcome of E2 binding to ER (1-5). Prior to these experiments, we confirmed E2 regulation of ER and PR levels in MCF-7 cells under the experimental conditions used in this study with receptor assays and Western blot analysis (data not shown). With E2 pretreatment, MIF more effectively activated Rb by approximately 205 and $37.5 \%$ at 24 and 48 h of treatment, respectively (Fig. 3A), while 4OHT less effectively activated $\mathrm{Rb}$ [a reduction in activation of approximately 75 and $64 \%$ at 24 and $48 \mathrm{~h}$ of treatment, respectively (Fig. 3B)]. Importantly, for the combined therapy, pretreatment with $\mathrm{E} 2$ increased $\mathrm{Rb}$ activation by approximately
$27 \%$ at $24 \mathrm{~h}$ and only modestly reduced $\mathrm{Rb}$ activation at $48 \mathrm{~h}$ by approximately $18 \%$ (Fig. 3C). Thus, MIF action through $\mathrm{PR}$ is able to compensate, in part, for E2-mediated protection against 4-OHT efficacy.

We also performed additional experiments in which excess E2 $(1.0 \mu \mathrm{M})$ was used to block 4-OHT binding to ER (Fig. 4). These studies demonstrated that $1.0 \mu \mathrm{M}$ E2 completely inhibited 4-OHT-induced $\mathrm{Rb}$ activation; the $\mathrm{pRb}$ :ppRb ratio did not increase in response to 4-OHT treatment. This protection by excess E2 was readily apparent at $72 \mathrm{~h}$ of treatment (Fig. 4A and $\mathrm{B}$; compare lanes 1 and 2 ). In contrast, excess E2 did not inhibit MIF-mediated $\mathrm{Rb}$ downregulation, which was the predominant effect of MIF at $72 \mathrm{~h}$ of treatment (Fig. 4A and B, compare lane 3 ). In the presence of excess E2, combination therapy was still able to reduce $\mathrm{Rb}$ protein levels in a similar fashion to that of the MIF treatment groups (Fig. 4A and B, compare lanes 3 and 4). These results were consistent with the antiproliferation assays performed in the presence of excess E2 in which MIF plus 4-OHT combination treatment was able to effectively block MCF-7 cell growth, i.e. $70 \%$ inhibition compared to $60 \%$ inhibition at $72 \mathrm{~h}$ (Fig. 1C), while excess E2 completely blocked 4-OHT antiproliferative activity (Fig. 1A). Taken together, the E2 pretreatment studies and the action of excess E2 provide good evidence that 4-OHT and MIF action involves $\mathrm{Rb}$ activation and its subsequent downregulation, and requires ER and PR, and MIF action through PR is able to compensate, in part, for E2-mediated protection against 4-OHT efficacy.

4-OHT plus MIF treatment only modestly increased breast cancer growth arrest as compared to either monotherapy. To address the physiological significance of Rb activation and/ or $\mathrm{Rb}$ downregulation, we used flow cytometry to analyze how 4-OHT and/or MIF treatments impacted the cell cycle. Both treatment conditions described for the $\mathrm{Rb}$ studies were analyzed. Analysis of the asynchronous, dividing cell population showed that all treatments (E2 ablation, 4-OHT, MIF, and 4-OHT plus MIF) resulted in an accumulation of cells in the G0/G1 phase together with a significant reduction in the number of cells in the $\mathrm{S}$ phase when compared to the E2-treated control cells, although the time course of the effects of the different treatments was slightly altered (Table II). Also, MIF in comparison to 4-OHT therapy was not as effective in inducing G0/G1 arrest but the small increase in the G0/G1 phase of the cell cycle induced by MIF was significant. With time, a significant decrease in the number of cells in the G2/M phase of the cell cycle was also noted after all treatments relative to E2 control cells. Only at the 24-h time point did combination treatment more effectively induce G0/G1 growth arrest than 4-OHT monotherapy, with a reduction in S-phase cells, and the difference, although statistically significant, was small; $80 \%$ versus $75 \%$. Similar effects on cell cycle were obtained when cells were growth arrested prior to treatment (withdrawal of insulin from DMEM/F12 for $24 \mathrm{~h}$ ) (data not shown). Overall, these data are in agreement with the well described role of hypophosphorylated Rb in blocking the G1-S transition (40-45) and the fact that MIF treatment induces G1 and $\mathrm{G} 2 / \mathrm{M}$ arrest (46-48). However, the increased ability of combination therapy to induce growth arrest was modest compared to the monotherapies. So, it did not appear that the 
A

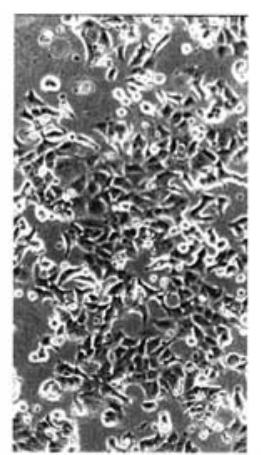

B

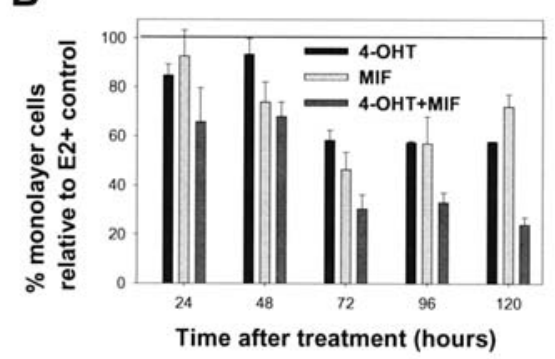

C
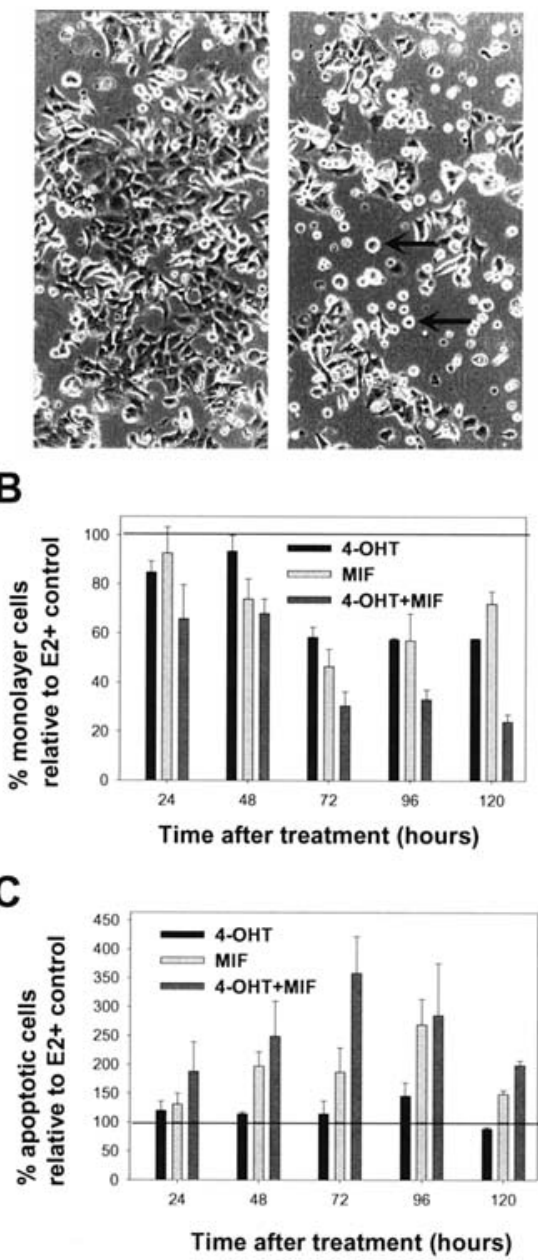

D
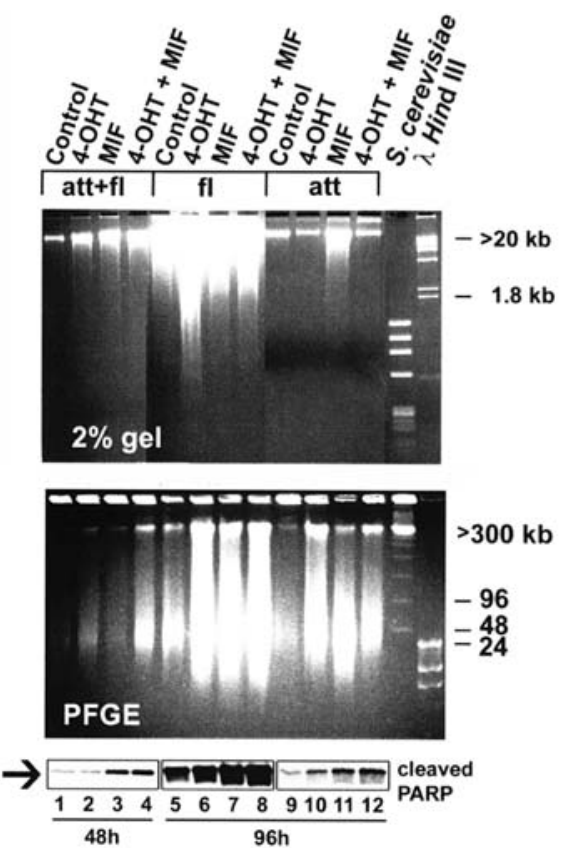

E

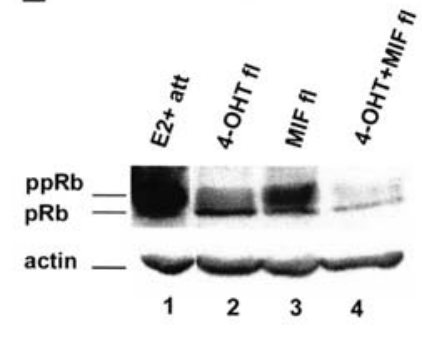

Figure 5. 4-OHT plus MIF combination therapy more effectively induced apoptosis and Rb downregulation than either monotherapy. 4-OHT and MIF monotherapies induced cell lifting from the MCF-7 monolayer (A-C). Following E2 depletion, MCF-7 cells were evenly seeded in 100-mm culture dishes and allowed to attach to the dish. After $24 \mathrm{~h}$, the MCF-7 cells were washed to remove insulin and then treated with physiological levels of E2 (10.0 nM) and either 4-OHT $(1.0 \mu \mathrm{M})$, MIF $(10.0 \mu \mathrm{M})$ or combination therapy (4-OHT + MIF). Live cell images were captured at x200 magnification with SPOT software using phase-contrast microscopy. (A) Cells treated for $96 \mathrm{~h}$ with E2 only showed few floating cells. In contrast, cells treated with E2 plus 4-OHT and MIF showed a significant increase in the number of floating cells (designated with black arrows) as compared to attached cells. For each treatment group, the number of monolayer versus detached (floating) cells is shown (B and C) at the indicated times. (D) Top panel, internucleosomal DNA laddering was not detected in 4-OHT- and/or MIF-treated MCF-7 cells. Conventional gel electrophoresis was performed on genomic DNA isolated according to the methodology of Ishida et al (33) that is optimized for detection of the internucleosomal DNA ladder (discrete multiple of $>180$-bp DNA fragments). DNA laddering was not observed in any of the treatment groups (lanes 1-12) of the 2\% agarose gel. $\lambda$ DNA ladder and HindIII-digested $\lambda$ DNA served as size standards, lanes 13 and 14, respectively. Middle panel, PFGE demonstrates HMW genomic DNA fragmentation in MCF7 cells undergoing 4-OHT- and/or MIF-induced cell death. An increase of HMW DNA of $>20 \mathrm{~kb}$ was seen in the floating cell population following 4-OHT and MIF treatment (lanes 6,7 and 8) as compared to the attached cell population (lanes 9-12). The DNA fragments were approximately 50 and $300 \mathrm{~kb}$ in size. S. cerevisiae chromosomes and HindIII-digested $\lambda$ DNA served as size standards, lanes 13 and 14, respectively. Bottom panel, Western analysis shows increased cleaved PARP levels in the floating (fl) cell population as compared to the attached, monolayer cell population. (E) Rb phosphorylation status in MCF-7 cells that have detached due to treatment with 4-OHT and/or MIF. After treatment for $60 \mathrm{~h}$, the detached cells were collected independently of each other and analyzed by Western blotting. The Rb status of the attached cells (designated att) growing in E2 (lane 1) can be compared to the Rb status of floating cells (designated fl) treated with E2 and 4-OHT, MIF or their combination (lanes 2-4).

increased efficacy of 4-OHT plus MIF therapy in reducing MCF-7 breast cancer cell growth was due to its cytostatic action.

4-OHT plus MIF combination therapy induced cell death concomitant with loss of Rb protein levels. Because the cytostatic action induced by 4-OHT plus MIF monotherapy was very similar to that of 4-OHT monotherapy (Table II), we hypothesized that the increased efficacy of 4-OHT plus MIF therapy was primarily through its ability to induce cell death $(27,29)$ and that the reduction in Rb protein levels was critical to the cytotoxic action. Therefore, we further analyzed the death process and the potential role of $\mathrm{Rb}$ downregulation in 4-OHT- and MIF-induced dying MCF-7 cells. First, we determined that even upon an extended time interval (up to $120 \mathrm{~h}$ ) 4-OHT plus MIF combination therapy induced cell detachment in only $30-50 \%$ of the cell population (Fig. 5A-C). The detached (floating) cell population was determined to be the dying cell population because $\sim 50 \%$ of the detached cells were trypan blue positive, whereas $<5 \%$ of the monolayer (attached cells) were trypan blue positive (data not shown). We further determined that the typical DNA laddering that results from cleavage of genomic DNA between nucleosomes during apoptosis was not present in the detached cell population 
Table III. Cell cycle characterization of 4-OHT- and/or MIF-treated monolayer versus detached cells .

\begin{tabular}{|c|c|c|c|c|c|c|}
\hline & \multicolumn{3}{|c|}{ Monolayer cells } & \multicolumn{3}{|c|}{ Detached cells (dying cells) } \\
\hline & $\% \mathrm{G} 0 / \mathrm{G} 1$ & $\% \mathrm{G} 2$ & $\% \mathrm{~S}$ & $\% \mathrm{G} 0 / \mathrm{G} 1$ & $\% \mathrm{G} 2$ & $\% \mathrm{~S}$ \\
\hline \multicolumn{7}{|l|}{$24 \mathrm{~h}$} \\
\hline $\mathrm{E}^{+}+$ & $69.4 \pm 0.9$ & $6.9 \pm 0.2$ & $23.8 \pm 1.2$ & & & \\
\hline 4-OHT & $82.6 \pm 0.6$ & $7.8 \pm 0.4$ & $9.7 \pm 0.2$ & & & \\
\hline MIF & $77.3 \pm 1.6$ & $6.1 \pm 0.6$ & $16.6 \pm 1.0$ & & & \\
\hline 4-OHT + MIF & $81.2 \pm 1.5$ & $8.8 \pm 0.0$ & $10.0 \pm 1.5$ & & & \\
\hline \multicolumn{7}{|l|}{$48 \mathrm{~h}$} \\
\hline $\mathrm{E} 2^{+}$ & $80.1 \pm 0.4$ & $5.7 \pm 0.6$ & $14.1 \pm 1.0$ & $64.74 \pm 0.0$ & $14.39 \pm 0.0$ & $20.88 \pm 0.0$ \\
\hline 4-OHT & $90.5 \pm 0.4$ & $2.5 \pm 0.4$ & $7.1 \pm 0.0$ & $79.37 \pm 0.0$ & $8.42 \pm 0.0$ & $12.21 \pm 0.0$ \\
\hline MIF & $85.5 \pm 2.3$ & $4.1 \pm 0.8$ & $10.4 \pm 1.5$ & $62.32 \pm 1.65$ & $16.16 \pm 0.17$ & $21.54 \pm 1.48$ \\
\hline $4-\mathrm{OHT}+\mathrm{MIF}$ & $92.9 \pm 0.2$ & $2.7 \pm 0.2$ & $4.4 \pm 0.0$ & $80.09 \pm 1.70$ & $8.88 \pm 0.94$ & $11.05 \pm 0.76$ \\
\hline \multicolumn{7}{|l|}{$72 \mathrm{~h}$} \\
\hline $\mathrm{E} 2^{+}$ & $80.8 \pm 0.7$ & $5.9 \pm 0.9$ & $13.3 \pm 0.2$ & $70.55 \pm 0.73$ & $13.23 \pm 2.07$ & $16.24 \pm 2.80$ \\
\hline 4-OHT & $91.7 \pm 0.4$ & $3.2 \pm 0.0$ & $5.1 \pm 0.4$ & $88.33 \pm 0.07$ & $5.42 \pm 0.51$ & $6.26 \pm 0.43$ \\
\hline MIF & $83.1 \pm 0.3$ & $5.2 \pm 0.1$ & $11.7 \pm 0.4$ & $68.15 \pm 0.28$ & $14.86 \pm 2.34$ & $17.00 \pm 2.05$ \\
\hline 4-OHT + MIF & $91.9 \pm 0.1$ & $3.2 \pm 0.3$ & $4.9 \pm 0.2$ & $87.90 \pm 0.69$ & $5.13 \pm 0.73$ & $6.98 \pm 1.43$ \\
\hline
\end{tabular}

MCF-7 cells were treated as described in Materials and methods with $1 \mu \mathrm{M}$ 4-OHT, $10 \mu \mathrm{M}$ MIF or their combination $(1 \mu \mathrm{M} 4-\mathrm{OHT}+10 \mu \mathrm{M}$ MIF. For each treatment group, two independent experiments were performed and the mean calculated. SEM, standard error of the mean. Insulin was removed at time of treatment.

(Fig. 5D), but increased levels of HMW genomic DNA fragmentation $(50 \mathrm{~kb}$ and $>300 \mathrm{~kb})$ as compared to the monolayer cells were clearly present (Fig. 5D, lanes 5-8 compared to lanes 1-4). Degradation of genomic DNA into these HMW fragments corresponds to the early genomic DNA cleavage events that occur during apoptotic cell death (49-51). The lack of DNA laddering is consistent with the fact that MCF-7 cells do not express caspase 3 (52) and, therefore, are unable to further degrade the HMW DNA fragments into internucleosomal DNA fragments. The detached cell population showed high levels of increased PARP cleavage resulting in the 89-kd fragment (Fig. 5D, bottom panel); a recognized marker of caspase-dependent apoptosis $(53,54)$. The cleavage of PARP into the 89-kd fragment and the degradation of DNA into HMW fragments demonstrates that 4-OHT- and MIF-induced detached cells were undergoing active cell death and that combination therapy is more cytotoxic than either monotherapy. Importantly, Rb protein levels were significantly reduced in the detached cells resulting from treatment with 4-OHT plus MIF combination therapy as compared to $\mathrm{Rb}$ protein levels in detached cells resulting from 4-OHT or MIF treatment (Fig. 5E, lane 4 compared to lanes 1-3). In detached cells treated with 4-OHT, Rb was primarily hypophosphorylated (Fig. 5E, lane 2), while in MIF-treated detached cells, $\mathrm{Rb}$ was hyperphosphorylated, as well as hypophosphorylated (Fig. 5E, lane 3). The status of Rb in these cell populations suggested that cells treated with 4-OHT or 4-OHT plus MIF combined therapy die primarily while in G1 or G0 growth arrest, while MIF treated cells die in all phases of the cell cycle. To determine the cell cycle phase(s) of the detached cells, we performed flow cytometry on the floating cell populations separate from the attached cell populations (monolayer cells). We reasoned that this analysis would be successful because the HMW DNA in the detached population is very stable and not degraded into internucleosomal DNA over a 7-day period (data not shown). Results from the flow cytometry are shown in Table III. As in the previous experiment (Table II), flow cytometry did not detect a sub-G1 peak, consistent with the absence of internucleosomal DNA cleavage and subsequent loss of these fragments from the dying cells. Importantly, cells dying in response to combination therapy are primarily in the G1 or G0 phase of the cell cycle similar to the 4-OHT-treated cells. Thus, combined therapy appears to induce death more effectively in the growth arrested population and this effect appears to be mediated by $\mathrm{Rb}$ protein downregulation that is maximal in cells treated with 4-OHT plus MIF combination therapy.

Knockdown of $R b$ with siRNA targeting increased the cytotoxic action of 4-OHT. Although the mechanism of 4-OHT- and MIF-induced $\mathrm{Rb}$ downregulation is not known, semiquanitative PCR was performed and demonstrated that Rb1 transcript levels were similar in cells treated with 4-OHT, MIF, or 4-OHT plus MIF combined therapy for $72 \mathrm{~h}$ (Fig. 6A). Thus, Rb protein loss appears to facilitate hormonally induced apoptosis. We reasoned that siRNA targeting and blockade of $\mathrm{Rb}$ translation in MCF-7 cells could recapitulate this scenario and similarly affect a death response. Thus, we performed siRNA targeting studies to test this hypothesis. Following a 144-h treatment period, cells were harvested for total protein and analyzed for levels of Rb1 (p110), cleaved PARP, and lamin A (Fig. 6B). In addition, cells were counted using 
A
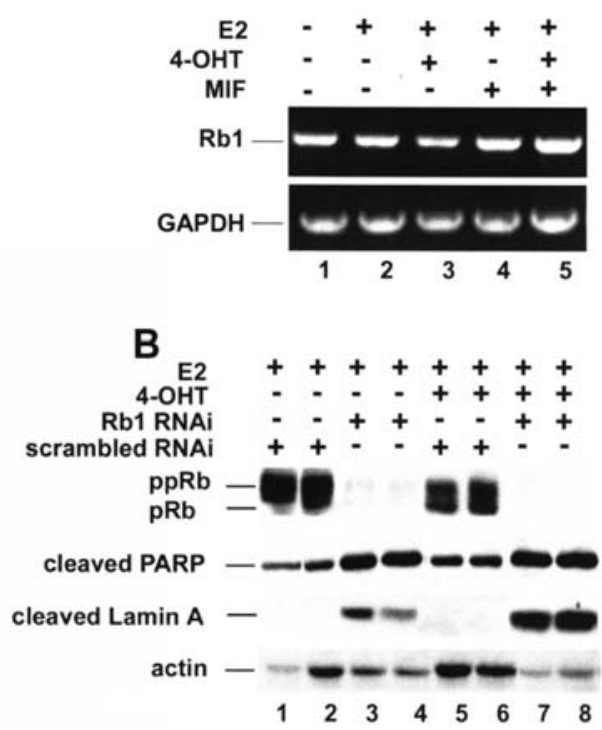

C

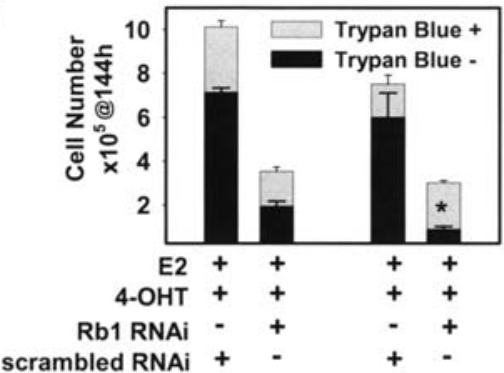

D

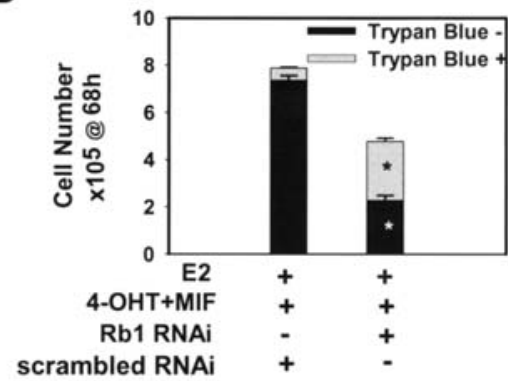

Figure 6. Decreased Rb protein levels in MCF-7 cells increased the cytotoxic action of 4-OHT. A, RT PCR analysis performed as described in Materials and methods demonstrated that the reduction of Rb1 (p110 protein) in response to 4-OHT plus MIF therapy did not occur at the level of mRNA transcription. B, siRNA knockdown of Rb induced cell death in MCF-7 cells as evidenced by increased levels of cleaved PARP and lamin A, two definitive markers of cell death. siRNA knockdown of Rb1 (p110) was performed according to the protocol supplied by Dharmacon. Forty-eight h following siRNA treatment, cells were treated with either E2 or E2 plus 4-OHT, and harvested for protein $144 \mathrm{~h}$ following hormonal therapy as described in Materials and methods. Knockdown was partial but detectable by $48 \mathrm{~h}$ of siRNA treatment (data not shown), and by $144 \mathrm{~h}$, Rb1 protein was barely detectable by Western blotting (lanes 3, 4, 7, and 8 compared to lanes $1,2,5$, and 6, respectively). C and D, siRNA knockdown of Rb1 reduced MCF-7 cell number and viability in two independent experiments. C, hormonal treatment was delivered to cells for $144 \mathrm{~h}$; D, hormonal treatment of cells was only $68 \mathrm{~h}$. The inability of cells to exclude trypan blue demonstrated loss of membrane integrity and cell death.

trypan blue exclusion as a measure of death (Fig. 6C). The experiment was carried out in triplicate and two independent experiments were executed. In addition, a separate experiment was carried out on MCF-7 cells freshly purchased from the ATCC. A final experiment was carried out in which MCF-7 cells were treated with E2 plus 4-OHT plus MIF in the presence of non-targeting siRNA or Rb1 siRNA. The cells from this treatment were harvested at $68 \mathrm{~h}$ after hormonal therapy in order to prevent dying cells from disintegrating. This time frame does not allow the full expression of loss of membrane integrity (trypan blue positive) in the cells treated with scrambled RNA but showed the increased cytotoxic effect mediated by combined hormonal therapy when Rb1 was downregulated by siRNA targeting These independent studies clearly demonstrated that siRNA targeting of Rb resulted in a significant reduction in Rb110 protein levels (Fig. 6B) and that this reduction was cytotoxic to $\mathrm{MCF}-7$ cells undergoing 4-OHT treatment. Both an increase in trypan blue uptake (Fig. 6C and D) and increased cleavage of PARP and lamin A (Fig. 6B) were detected in cells lacking Rb expression. Thus, a loss of $\mathrm{Rb}$ protein significantly facilitates cell death induced by 4-OHT treatment. Based on these studies, we conclude that $\mathrm{Rb}$ is critical to facilitate growth arrest, but that its loss is necessary for 4-OHT-induced cytotoxic action.

\section{Discussion}

In this pre-clinical in vitro study, we have analyzed the underlying antiproliferative mechanism(s) of antiestrogen and antiprogestin therapy in hormone-dependent breast cancer cells.
We provide strong evidence in MCF-7 cells that: i) 4-OHT and MIF action is mediated primarily through the ER and PR; ii) the antiproliferative effects of MIF treatment are enhanced by E2, not abrogated by E2 as is the case for 4-OHT action; and iii) 4-OHT plus MIF therapy ultimately downregulates Rb p110 levels in growth arrested cells which is required for efficient execution of apoptosis in antiestrogen-treated breast cancer cells. Downregulation of Rb with RNA interference confirmed that $\mathrm{Rb}$ protein loss induces death in hormonally-treated MCF-7 cells. Collectively, these data provide a mechanistic rationale for the use of MIF and potentially other antiprogestins in the treatment of breast cancer.

In this study (Fig. 1A and B) and our previous pre-clinical studies (27-29), the MIF concentration $(10.0 \mu \mathrm{M})$ required to reduce MCF-7 cell growth in vitro by approximately $50 \%$ in a 72- to 96-h treatment time interval is ten times higher than that required for 4-OHT $(1.0 \mu \mathrm{M})$. At this concentration, however, MIF action does appear to be ER- and PR-mediated because growth of the ER- and PR-negative MDA 231 cells is not blocked by $10 \mu \mathrm{M}$ MIF (data not shown). In fact, our recently published study demonstrates that concentrations of $8.0 \mu \mathrm{M}$ 4-OHT and 25.0 $\mu \mathrm{M}$ MIF are required to achieve $\mathrm{Rb}$ activation and $50 \%$ growth inhibition of MDA-231 cells at $72 \mathrm{~h}$ of treatment (55).

This study clearly identifies $\mathrm{Rb}$ activation as the main molecular target of 4-OHT monotherapy with cell cycle arrest as a primary outcome (Figs. 2-4, Table II). Rb activation by 4-OHT is consistent with several published studies, including those conducted in T-47D breast cancer cells $(56,57)$. In addition, we uniquely show that the cytotoxic action of 4-OHT 
plus MIF hormonal therapy directly correlated to $\mathrm{Rb}$ protein downregulation. The mechanism of downregulation did not occur at the level of transcription (Fig. 6A) and is currently under investigation in our laboratory. We have demonstrated the physiological significance of $\mathrm{Rb}$ downregulation using siRNA knockdown studies to mimic Rb protein downregulation by MIF. Under conditions of Rb protein reduction, MCF-7 cells treated with E2 underwent cell death (Fig. 6C). Importantly, $\mathrm{Rb}$ knockdown plus 4-OHT treatment resulted in an additive cytotoxic effect in a manner similar to that characterized for 4-OHT plus MIF combined therapy. Thus, we conclude that at least part of the mechanism of MIF action is in its ability to downregulate active $\mathrm{Rb}$ in 4-OHT-treated cells and allow apoptotic cell death to proceed. Because we $(59,60)$ and Bursch et al (58) have demonstrated that 4-OHT and the antiestrogen ICI 164-384 induce active cell death II (ACD II) in MCF-7 cells, our laboratory is currently analyzing the role of active $\mathrm{Rb}$ in the regulation of macroautophagy and ACD II. Our unpublished studies indicate that the high level of lamin A cleavage (Fig. 6B) following $\mathrm{Rb}$ downregulation is due to a caspase-dependent apoptosis occurring in cells undergoing autophagy (Gaddy et al, manuscript in preparation). These data support the potential role of $\mathrm{Rb}$ in regulating autophagy in growth arrested cells, which if correct adds a new dimension to the role of this tumor suppressor protein and warrants further investigation.

We should note that our Rb siRNA studies show a different outcome then recent $\mathrm{Rb}$ siRNA studies conducted by Bosco and co-workers, in which Rb1 knockdown via siRNA is correlated to an increased growth rate of MCF-7 cells in vitro and in vivo (61). Although we cannot definitively identify the discrepancy in results, we suggest that our studies utilize MCF-7 cell populations; whereas, the study by Bosco and coworkers analyzed cell lines that were derived through clonal selection following siRNA treatment. Thus, it is conceivable that in the study by Bosco et al, clonal selections resulted in $\mathrm{MCF}-7$ cells with mutations that compensated for $\mathrm{Rb}$ protein loss, a prediction that is consistent with the de-regulation of the $\mathrm{Rb}$ pathway associated with early recurrence following tamoxifen monotherapy described in their report. This explanation would also be consistent with our previous studies that have identified a large number of variants that can be selected from the MCF-7 cell line through clonal selections, including antiestrogen-resistant cell lines (29).

In summary, these pre-clinical studies provide strong evidence that the well-known cytostatic effects mediated by antiestrogen therapy can be improved significantly by cotreatment with an antiprogestin, such as MIF. Although some studies have determined that MIF at a low dose may act in an estrogenic fashion under different experimental conditions (25-27), low-dose MIF treatment did not stimulate MCF-7 cell growth under our treatment conditions (data not shown). Thus, this pre-clinical study and our published pre-clinical studies (27-29) support a role for MIF to be used in combination with 4-OHT therapy for the treatment of $\mathrm{ER}^{+}$breast cancer. Pre-clinical studies by others $(31,46-48)$ also support a role for MIF in the treatment of breast cancer, particularly a recent study (30) demonstrating a potential role for MIF in the chemoprevention of Brca1-associated breast cancer. To date, only a limited number of clinical trials have been conducted with MIF (62-64) and these trials were evaluating the use of MIF as a monotherapy, not as a combined therapy with an antiestrogen regimen. However, during these trials, MIF was well tolerated, particularly if used at a 200-mg daily dose that did not appear to exert antiglucocorticoid activity. In addition, a recent clinical study showed a good toleration for MIF in the long-term treatment of meningioma (65). Therefore, MIF cytotoxicity should not be a major problem and antiestrogen and MIF combination therapy of $\mathrm{ER}^{+}$breast cancer patients may be well tolerated and more efficacious than antiestrogen monotherapy.

\section{References}

1. Katzenellenbogen BS and Katzenellenbogen JA: Estrogen receptor transcription and transactivation: estrogen receptor alpha and estrogen receptor beta: regulation by selective estrogen receptor modulators and importance in breast cancer. Breast Cancer Res 2: 335-344, 2000

2. Henderson BE, Roos R and Bernstein L: Estrogens as a cause of human cancer. The Richard and Hinda Rosenthal Foundation Award lecture. Cancer Res 48: 246-253, 1988.

3. Katzenellenbogen BS, Choi I, Delage-Mourroux R, Ediger TR, Martini PG, Montano M, Sun J, Weis K and Katzenellenbogen JA: Molecular mechanisms of estrogen action: selective ligands and receptor pharmacology. J Steroid Biochem Mol Biol 74: 279-285, 2000 .

4. Katzenellenbogen BS: Estrogen receptors: bioactivities and interactions with cell signaling pathways. Biol Reprod 54: 287-293, 1996.

5. Katzenellenbogen BS: Mechanisms of action and cross-talk between estrogen receptor and progesterone receptor pathways. J Soc Gynecol Investig 7 (suppl 1): S33-S37, 2000.

6. Jordan VC: Third Annual William L. McGuire Memorial Lecture. 'Studies on the estrogen receptor in breast cancer' - 20 years as a target for the treatment and prevention of cancer: Breast Cancer Res Treat 36: 267-285, 1995.

7. Early Breast Cancer Trialists' Collaborative Group: Tamoxifen for early breast cancer: an overview of the randomized trials. Lancet 351: 1451-1467, 1998.

8. Kuter I: Breast cancer update. Oncologist 5: 285-292, 2000.

9. Fisher B, Costantino JP, Wickerham DL, Redmond CD, Kavanah DM, Wieand S, Tan-Chiu E, Ford L and Wolmark N: Tamoxifen for prevention of breast cancer: report of the National Surgical Adjuvant Breast and Bowel Project P-1 study. J Natl Cancer Inst 90: 1371-1388, 1998.

10. Ariazi EA, Ariazi JL, Cordera F and Jordan VC: Estrogen receptors as therapeutic targets in breast cancer. Curr Top Med Chem 6: 181-202, 2006.

11. Nicholson RI and Johnston SR: Endocrine therapy - current benefits and limitations. Breast Cancer Res Treat 93: S3-S10, 2005.

12. Gill PG, Vignon F, Bardon S, Derocq D and Rochefort H: Difference between R5020 and the antiprogestin RU486 in antiproliferative effects on human breast cancer cells. Breast Cancer Res Treat 10: 37-45, 1987.

13. Baker GH, Setyono-Han B, de Jong FH and Klijn JGM: Mifepristone in treatment of experimental breast cancer in rats. In: Hormonal Manipulation of Cancer: Peptides, Growth Factors and New (Anti) Steroidal Agents. Klijhn, Paridaens and Foekens (eds). Raven, New York, pp39-48, 1987.

14. Philibert D, Moguilewsky M, Mary I, Lecaque D, Tournemine C, Secclu J and Deraedt R: Pharmacological profile of RU486 in animals. In: The Antiprogestin Steroid RU 486 and Human Fertility Control. Baulieu and Segal (eds). Plenum Press, New York, pp49-68, 1985.

15. Hermann WL, Schindler AM, Wyss R and Bischof P: Effects of the antiprogesterone RU 486 in early pregnancy and during the menstrual cycle. In: The Antiprogestin Steroid RU 486 and Human Fertility Control. Baulieu and Segal (eds). Plenum Press, New York, pp179-198, 1985.

16. Healy DL, Chrousos GP, Schute HM, Williams RF, Gold PW, Baulieu EE and Hodgen GD: Pituitary and adrenal responses to the anti-glucocorticoid steroid RU 486 in primates. J Clin Endocrinol Metab 57: 863, 1983. 
17. Schaison G, George M, Lestrat M, Reinberg A and Baulieu EE: Effects of the antiprogesterone steroid RU 486 during midluteal phase in normal women. J Clin Endocrinol Metab 61: 484-489, 1985.

18. Gravanis A, Schaison G, George M, Brux J, de Satayaswaroop PG, Baulieu EE and Robel P: Endometrial and pituitary responses to the steroidal antiprogestin RU 486 in postmenopausal women. $\mathrm{J}$ Clin Endocrinol Metab 60: 156-163, 1985.

19. Horwitz KB: The antiprogestin RU 38 486: receptor mediated progestin versus antiprogestin actions screened in estrogeninsensitive T-47D human breast cancer cells. Endocrinology 116: 2236-2245, 1985.

20. Horwitz KB: The molecular biology of RU486. Is there a role for antiprogestins in the treatment of breast cancer? Endocr Rev 13: 146-163, 1992.

21. Weigel N: Overview and background: mechanism of action of antiprogestins. Clinical application of mifepristone (RU486) and other antiprogestins. In: Assessing the Science and Recommending a Research Agenda. Donaldson, Dorflinger, Brown and Benet (eds). National Academy Press, Washington DC, pp120-138, 1993.

22. Bertagna X, Bertagna C, Luton JP, Husson JM and Girard F: The new steroid analog RU486 inhibits glucocorticoid action in man. J Clin Endocrinol Metab 59: 25, 1984.

23. Gaillard RC, Riondel A, Muller AF, Hermann W and Baulieu EE: RU486: studies of its antiglucocorticosteroid activity in man. In: Antiprogestin Steroid RU486 and Human Fertility Control. Baulieu (ed). SJ Segal Plenum Press, New York, p331, 1985.

24. Kraus WL, Weis KE and Katzenellenbogen BS: Inhibitory crosstalk between steroid hormone receptors: differential targeting of estrogen receptor in the repression of its transcriptional activity by agonist-and antagonist-occupied progestin receptors. Mol Cell Biol 15: 1847-1857, 1995.

25. McDonnell DP and Goldman ME: RU486 exerts antiestrogenic activities through a novel progesterone receptor A form-mediated mechanism. J Biol Chem 269: 11945-11949, 1994.

26. Jeng MH, Langanfahey SM and Jordan VC: Estrogenic actions of RU486 in hormone-responsive MCF-7 human breast cancer cells. Endocrinology 132: 2622-2630, 1993.

27. El Etreby MF, Liang Y, Wrenn RW and Schoenlein PV: Additive effect of mifepristone and 4-hydroxytamoxifen on apoptotic pathways in MCF-7 human breast cancer cells. Breast Cancer Res Treat 51: 149-168, 1998.

28. El Etreby MF and Liang Y: Effect of antiprogestins and 4hydroxytamoxifen on growth inhibition of MCF-7 human breast cancer cells in nude mice. Breast Cancer Res Treat 49: 109-117, 1998.

29. Gaddy VT, Barrett JT, Delk JN, Kallab AM, Porter AG and Schoenlein PV: Mifepristone induces growth arrest, caspase activation, and apoptosis of estrogen receptor-expressing, antiestrogen-resistant breast cancer cells. Clin Cancer Res 10: 5215-5225, 2004

30. Poole AJ, Li Y, Kim Y, Lin SC, Lee WH and Lee EY: Prevention of Brca1-mediated mammary tumorigeneisis in mice by a progesterone antagonist. Science 314: 1467-1470, 2006.

31. Bardon S, Vignon F, Montcourrier P and Rochefort H: Steroid receptor-mediated cytotoxicity of an antiestrogen and an antiprogestin in breast cancer cells. Cancer Res 47: 1441-1448, 1987.

32. Wataha JC, Craig RG and Hanks CT: Precision of new methods for testing in alloy cytotoxicity. Dent Mater 8: 65-71, 1992.

33. Ishida Y, Agata Y, Shibahara K and Honjo T: Induced expression of PD-1 - a novel member of the immunoglobulin gene superfamily upon programmed cell death. EMBO J 11: 3887-3895, 1992.

34. Schoenlein PV, VanDevanter D and Gottesman MM: Extrachromosomal elements in mammalian cells. In: Methods in Molecular Genetics. Adolph KW (ed). Academic Press, San Diego, pp78-103, 1993.

35. Sanchez AM, Barrett JT and Schoenlein PV: Fractionated ionizing radiation accelerates loss of amplified MDR1 genes harbored by extrachromosomal DNA in tumor cells. Cancer Res 58: 3845-3854, 1998 .

36. Schoenlein PV, Barrett JT and Welter D: The degradation profile of extrachromosomal circular DNA during cisplatininduced apoptosis is consistent with preferential cleavage at matrix attachment regions. Chromosoma 108: 121-131, 1999.

37. Thangaraju M, Gopal E, Martin PM, Ananth S, Smith SB, Prasad PD, Sterneck E and Ganapathy V: SLC5A8 triggers tumor cell apoptosis through pyruvate-dependent inhibition of histone deacetylases. Cancer Res 66: 11560-11564, 2006.
38. Formby B and Wiley TS: Progesterone inhibits growth and induces apoptosis in breast cancer cells: inverse effects on Bcl-2 and p53. Ann Clin Lab Sci 28: 360-369, 1998.

39. Cariou S, Donovan JCH, Flanagan WM, Milic A, Bhattacharya N and Slingerland JM: Down-regulation of p21 WAF1/CIP1 or p27 Kip1 abrogates antiestrogen-mediated cell cycle arrest in human breast cancer cells. Proc Natl Acad Sci USA 97: 9042-9046, 2000 .

40. Musgrove EA, Lee CSL, Buckley MF and Sutherland RL: Cyclin D1 induction in breast cancer cells shortens G1 and is sufficient for cells arrested in G1 to complete the cell cycle. Proc Natl Acad Sci USA 91: 8022-8026, 1994.

41. Goodrich DW, Wang NP, Qian YW, Lee EY and Lee WH: The retinoblastoma gene product regulates progression through the G1 phase of the cell cycle. Cell 67: 293-302, 1991.

42. Sherr CJ: Cancer cell cycles. Science 274: 1672-1677, 1996.

43. Knudsen ES, Buckmaster C, Chen TT, Feramisco JR and Wang JY: Inhibition of DNA synthesis by RB: effects on G1/S transition and S-phase progression. Genes Dev 12: 2278-2292, 1998.

44. Weinberg RA: The retinoblastoma protein and cell cycle control. Cell 81: 323-330, 1995.

45. Sherr CJ: Mammalian G1 cyclins and cell cycle progression. Proc Assoc Am Physicians 107: 181-186, 1995.

46. Michna H, Schneider MR, Nishino $Y$ and El Etreby MF: Antitumor activity of the antiprogestins ZK98.299 and RU 38.486 in hormone dependent rat and mouse mammary tumors: mechanistic studies. Breast Cancer Res Treat 14: 275-288, 1989.

47. Michna H, Schneider MR, Nishino Y and El Etreby MF: The antitumor mechanism of progesterone antagonists is a receptor mediated antiproliferative effect by induction of terminal cell death. J Steroid Biochem Mol Biol 34: 447-453, 1989.

48. Schneider MR, Michna H, Nishino Y and El Etreby MF: Antitumor activity and mechanism of action of different antiprogestins in experimental breast cancer models. J Steroid Biochem Mol Biol 37: 783-787, 1990.

49. Oberhammer F, Wilson JW, Dive C, Morris ID, Wakeling JA, Walker PR, Sikorska M and Hickman JA: Apoptotic cell death in epithelial cells: cleavage of DNA to 300 and/or 50 kilobase fragments prior to or in the absence of internucleosomal fragmentation. EMBO J 12: 3679-3684, 1993.

50. Walker PR, Weaver VM, Lach B, LeBlanc J and Sikorska M: Endonuclease activities associated with high molecular weight and internucleosomal DNA fragmentation in apoptosis. Exp Cell Res 213: 100-106, 1994.

51. Filipski J, Leblanc J, Youdale T, Sikorska M and Walder PR: Periodicity of DNA folding in higher order chromatin structures. EMBO J 9: 1319-1327, 1990.

52. Janicke RU, Sprengart ML, Wati MR and Porter AG: Caspase-3 is required for DNA fragmentation and morphological changes associated with apoptosis. J Biol Chem 273: 9357-9360, 1998.

53. Virag L and Szabo C: The therapeutic potential of poly (ADPRibose) polymerase inhibitors. Pharmacol Rev 54: 375-429, 2002.

54. Gobeil S, Boucher CC, Nadeau D and Poirier GG: Characterization of the necrotic cleavage of poly (ADP-ribose) polymerase (PARP-1): implication of lysosomal proteases. Cell Death Diff 8: 588-594, 2001

55. Liang Y, Hou M, Kallab AM, Barrett JT, El Etreby F and Schoenlein PV: Induction of antiproliferation and apoptosis in estrogen receptor negative MDA-231 human breast cancer cells by mifepristone and 4-hydroxytamoxifen combination therapy: a role for TGFß1. Int J Oncol 23: 369-380, 2003.

56. Musgrove EA, Lee CSL, Cornish AL, Swarbrick A and Sutherland RL: Antiprogestin inhibition of cell cycle progression in T-47D breast cancer cells is accompanied by induction of the cyclin-dependent kinase inhibitor p21. Mol Endocrinol 11: 54-66, 1997.

57. Alban P, Hurd C, Dinda S, Khattree N and Moudgil VK: Differential regulation of retinoblastoma protein by hormonal and antihormonal agents in T47D breast cancer cells. J Steroid Biochem Mol Biol 77: 135-141, 2001.

58. Bursch W, Ellinger A, Kienzl H, Torok I, Pandy S, Sikovska M, Walker R and Hermann RS: Active cell death induced by the antiestrogens tamoxifen and ICI164384 in human mammary carcinoma cells (MCF-7) in culture: the role of autophagy. Carcinogenesis 17: 1595-1607, 1996.

59. Gaddy VT, Barrett JT, Delk JN and Schoenlein PV: Hormonallyinduced autophagocytic cell death in human breast cancer cells is caspase dependent. Am Assoc Cancer Res Proc 45: 1115-1116, 2004. 
60. Schoenlein PV, Barrett JT, Gaddy V, Welborn A, Delk J and Wrenn R: The phosphorylation status of the retinoblastoma protein and PKC delta correlate with the mechanism of active cell death induced by hormonal therapy of MCF-7 breast cancer cells: autophagocytic versus apoptotic cell death. Am Assoc Cancer Res Proc 44: 700, 2003.

61. Bosco EE, Wang Y, Xu H, Zilfou JT, Knudsen KE, Aronow BJ, Lowe SW and Knudsen ES: The retinoblastoma tumor suppressor modifies the therapeutic response of breast cancer. J Clin Invest 177: 218-228, 2007.

62. Klijn JGM, Setyono-Han B, Sander HJ, Lamberts SWJ, DeJong FH, Deckers GH and Foekens JA: Preclinical and clinical treatment of breast cancer with antiprogestins. In: Progesterone Antagonists in Reproductive Medicine and Oncology. Beier HM and Spitz IM (eds). Oxford University Press, Cambridge, UK. Human Reprod 9: 181-189, 1994.
63. Perrault D, Eisenhauer EA, Pritchard KI, Panasci L, Norris B, Vandenberg T and Fisher B: Phase II study of the progesterone antagonist mifepristone (RU486) in patients with untreated metastatic breast carcinoma. A National Cancer Institute of Canada Clinical Trials Group Study. J Clin Oncol 14: 2709-2712, 1996.

64. Romieu G, Maudelonde T, Ulmann A, Pujol H, Grenier J, Cavalie G, Khalaf S and Rochefort H: The antiprogestin RU 486 in advanced breast cancer: Preliminary clinical trial. Bull Cancer 74: 455-461, 1987.

65. Grunberg SM, Weiss MH, Russell CA, Spitz IM, Ahmadi J, Sadun A and Sitruk-Ware R: Long-term administration of mifepristone (RU486): clinical tolerance during extended treatment of meningioma. Cancer Invest 24: 727-733, 2006. 